\title{
RETIREMENT SYSTEM CHARACTERISTICS AND COMPENSATING WAGE DIFFERENTIALS IN THE PUBLIC SECTOR
}

\author{
RONALD G. EHRENBERG*
}

\begin{abstract}
This paper presents evidence that a trade-otf exists between wages and cer. tain characteristics of retirement systems in the public sector. Cross-section econometric estimates for uniformed municipal employees, based upon data from two national surveys of municipalities, suggest that, other things equal, an increase in the contribution made by unilormed employees to their retirement system leads to a compensating increase in their salaries, while retirement systums with more "generous" characteristics are associated to some extent with lower salaries. The estimates also indicate that the extent of retirement system underlunding is related to employers' and employees' perceptions of the probability that promised retirement benefits will not be fully paid and that these perceptions too are reflected in compensating wage differentials. The author concludes that pension reform legislation in the public sector will be likely to have an impact on public sector wages and, therefore, careful consideration should be given to the design of such legislation.
\end{abstract}

$T^{N}$ 1974, Congress passed a major piece of private sector pension reform legislation, the Einployee Retirement Income Security ACl (ERISA). ERISA was designed to increase the probability that private sector employees receive pensions. It included provisions requiring liberalized vesting rules, more striagent funding requirements,

\footnotetext{
* The author is a prolcssor of economics and indus trial and labor relationsat Cornell University. Resentrch support was provided by the National Science Founda. tion and inuch of the data used in the paper was provid. ed by the International City Manigement Association. Seminars based upon earlier versions of this paper were presented at several workshops. The author is gratelul to Mlan Marcus and David Rogers for lheir research assistance and to Edward Lazcar and Robert S. Smils for their comments.
}

and increased fiduciary responsibility. The need for, and wisdom of, ERISA-type con. trols over public employees' retirement systems is currently under debate. ${ }^{1}$

Unfortunately, as with many other government regulations, public sector pension reform legislation would likely have unintended side effects. ${ }^{2}$ Bccause ERISA-type

\footnotetext{
'The recent publication of U.S. House of Representatives, Committec on Education and Labor, Pew. sion Task Force Report on Public Employee Retive. ment Systems (Washington, D.C.i C.P.O., 1978), which contains a survey of state and local govern. ment relirement system characteristics, has added further fuel to the debate.

That ERISA itself had many "unintended" side effects is now widely recogutized and studies of the act's quantitative impact on a valiety of areas are cur-
} 
controls increase costs of providing pensions, one would expect governments to shift at least part of the increased costs to their employees in the form of lower wages. To the extent that the costs are not fully shilted, one would also expect lower levels of public employment and increased costs of public services (in the form of higher taxes). ${ }^{3}$ Hence, it is not obvious a priori that such legislation is socially desirable. As a prelude to a more complete evaluation of the desirability of public sector pension reform legislation, this paper seeks to ascertain if a trade. off exists between retirement system characteristics and wages in the public sector. 4

\section{The Trade-Off in the Public Sector}

Pension plans take many lorms, but most can be categorized as either "delined-con. tribution plans" or "defined-benefit plans." In defined-contribution plans, the amount of money contributed to an employee's account at each point in time is determined by such criteria as the employee's wage or the firm's profits. These contributions are in. vested by the firm or its agent, and the em. ployee receives no guarantee about the bene. fit levels that will be received upon retirement. Far more prevalent in the public sector than defined-contribution plans, however, are defined-benefit plans. ${ }^{5}$ In such

rently being conducted under Departunent of Labor funding.

sEvidence that wage elasticitics of demand for pubtic employees are negative is found in Orley Ashentelter and Ronald G. Elirenterg, "The Dentand for Latror in the Public Scetor" in Daniel IIamermesh, ed., Labor in the Public and Nonprofit Sectors (Princeton, N.J.: Princelon University Press, 1975), and Ronald G. Ehrenlerg, "The Demand lor State and Local Governmen Employees," American Economic Re. view, Vol. 113, No. 3 (June 1973), pp. $366-79$.

Two related prior studies are Alan Gustman and Martin Segal, "Teachers P'ensions: An Analysis of Interstate Variations," Industrial Relations, Vol. 16, No. 2 (October 1977), pp. $385-44$, and Randlal] Weiss and Bradley Schiller, "The Value of Defined Benefit Pension Plans: A Test of the Equalizing Diflerences Hypothesis," Quarterty Joumal of Economics (forth. coning). The lormer sought to identily the reasons for interstate differences in teachers' pensions; the latter focused on the trade-off between private sector wages and pension plan characteristics.

sRobert Tilove, Public Employee Pension Funds (New York: Columbia University Press, 1976). Why delined benefit plans predominate is an issue that is plans, the worker is guaranteed a pensioti of a given amount per year upon retirement. The benefit level is often a lunction of one or more factors, such as an employee's years of service and the wage over his or her tenure with the government.

Defined-benefit pension plans are typically quite complex and contain numerous provisions. These include minimum age and/or service requirements for receipt of benefits upon retirement; vesting rules; rules that specify which salary level enters into the calculation of a retiree's benefits (final year's, average of final $n$ years, career average, with or without overtime earnings, and so forth); required employee contribution rates to the retirement system; and a variety of rules that relaie to special situations (such as early retirement provisions, disability benefit provisions, provisions for death benefits for death prior to retiremen!, and survivors' options). ${ }^{6}$ Fortunately, in most cases it is straightforward to calculate how changing a provision will alter the net contributions that an employer must make each period to an employee's pension fund account in order to keep the account fully funded. For example, increasing employ. ees' required contribution rate will decrease.

not addressed here. Undoubtedly, the phenonenon reflects boil employees' risk aversion (preference for a certain nominal benefit Jesel) and government officials" "ability to underfund defined benefit plans. (See Gene Mumy, "The Economics of Local Government Peasions and Pension Funding," Journal of Political Economy, Vol. 86, No. 3 (June 1978), pp. 517-28. Extension of ERISA to the public sector would elininate the latter rationalc.

SSe Tilove, Public Employee Pension Funds; U.S. House of Representatives, Pension Task Force Report ...., and U.S. Conlerence of Mayors, Labor Management Relations Service (prepared by Edward $\mathbf{H}$. Friend \& Co.), Thitd National Survey of Employee Denejits for Full-Time Persomel of U.S. Munici. palities (Washington, D.C.: U.S. Conference of May. ors, 1977), tor a more complete description of the various provisions and the frequency with which they occur.

'Details of the methodology used in these calcula. tions are found in Burt $\mathbf{S}$. Barnow and Ronald $\mathbf{G}$. Elirenberg, "The Costs of Defined Benelit Pension Plans and Firm Adjustments," Quarterly Joumal of Economics, Vol. 93, No. 1 (November 1979), pp. 528 40, in which explicit employer net pension cost functions for several stylized defined-benclit pension plans ate derived. 
the employer's net pension costs, while increasing the generosity of the plan by increasing the level of retirement benefits that are received for each year of service will increase the employer's net pension costs, ceteris paribus. In general, the required employer net pension fund contribution per employee each period $(C)$ will be a function of the employee's current wage rate $(W)$ and of a vector $(R)$ of retirement system characteristics.

$$
C=C(W, R)
$$

Previous studies of public sector wage determination have shown that variations in wage scales of public employees across cities can be explained by a vector of variables, $X$, which represent the determinants of the demand for, and supply of, public employecs in a city, the extent of power of public employee unions, the extent of the local government's monopsony power, and the structure of the local government (as, for example, mayor-council or city manager). ${ }^{8}$ Suppose that public employers are indifferent as to how their total jabor costs are divided between wages and retirement system contributions; this will occur if each dollar that public employers devote to wages has the same impact on labor turnover, Iurnover costs, and employee productivity as each dollar that they devote to retirement system contributions. ${ }^{9}$ Under such condi.

\footnotetext{
ISe Ronald G, Elusenberg, "Municipal Government Structure, Unionization, and the Wages of Firefighues," Industrial and Labor Relations Review. Vol. 27, No. I (October 1973), pp. 96-48, and Ronald G. Ehrenberg and Gerald S. Goldstein, "A Model of Public Sector Wage Detcrmination," Joumnt of Urban Economics, Vol. 2, No. I (February 1975), pp, 228 -45.

'I his assumption ignores the elfect of deferred compensation schemes on life.cycle productivity growll (see Edward Lazear, "Why Is There Mandatory Retiremenı?" Joumal of Political Economy, Vol. 87, No. 6 (November-December 1979), pp. 126-85), tlie ellects of tax treatment of pension contributions (see Dontald Cymrot, "The Elfect of Tax Incentives on the Rate of Return for Private Pensions" (paper prrsented at the August 1978 Econometric Society Meecings)). and the possible clfects of retirement system parann. cters per se on labor turnover (see Jack Whiting, "Compensating Wage Dilfurentials and Pension Coverage" (Ph.D. Dissertation, Cornell University, 1979)). Whether these omissions are justified is an empirical question. Once the notion that employecs have "persmanent" attachments to a government is intro.
}

tions, the division of the compensation package between wages and nonwage liabor costs (defined here lor expository purposes to include only net pension contributions) would be determined by employee prefer. ences, and wages would adjust across cities with identical characteristics $(X)$ to equalize the total costs of public employees. Hence,

$$
W(X, R)+C(W, R)=\hat{W}(X) .
$$

Here $\hat{W}$ represents the wage scale func. tion for public employees in cities without public employee retirement systems and $W$ the function in cities with retirement systems. It immediately follows that for any retirement system provision $R_{i}$,

$$
\begin{gathered}
W / \partial R_{i}= \\
-\left(\partial C / \partial R_{j}\right) /(1+(\partial C / \partial W)) .
\end{gathered}
$$

Since increases in public employee wage scales never reduce public employers' net pension fund liabilities per employee $(\partial \mathrm{Cl} \partial W \geq \eta)$, changing any retirement system provision in a manner that increases employers' net pension fund liabilities per employee will lead to a reduction in public employees' wage scalcs. That is, other things equal, public employers with more generous pension plans will pay lower wages than public employers with less generous, or no, pension plans. Holding the characteristics of cities $(X)$ constant, market observations on public sector wages and retirement system characteristics would trace out the trade-off curve for municipal employers.

Clearly, this is a simplification. As Sher. win Rosen has superbly demonstrated, the observable markel trade-off is a reduced form determined by the interaction of both employers' and employees' preferences. To identify the underlying structural model and estimate the implicit demand and sup. ply "prices" of pension coverage would require a more detailed model that would include the roles of risk, tax treatment of pensions, differential rates of return on

duced, one may argue that Equation 2 below should be replaced by a weaker expression that inwolves present values. As a result, the empirical work reported in Table 1 also includes present value equations. 
governmental and individual investments, economies of scale in group provision of annuities, and the differential impact of pensions on turnover and turnover on productivity across cities. ${ }^{10}$ Sadly, the available data do not permit me to identify the underlying structural equations that would be generated from such a model. As such, although I "maintain" the liction that I am estimating the parameters of the employer trade-olf curve to derive testable implications, it should be understood that I am actually estimating reduced-form market equilibrium equations below.

\section{Empirical Analysis: 1973 Survey Data}

Based upon the analytic framework presented in the previous section, I specily estimating equations of the form

$$
W_{i j}=\alpha_{0}+\alpha_{1} X_{j}+\alpha_{2} R_{j}+u_{j}
$$

Here $W_{i j}$ represents the logarithm of the wage scale (entrance or maximum) of public employees in category $i$ (police or firefighters) in city $;, X_{j}$ is a vector of variables expected to influence the wages of public employees in city $j, R_{j}$ is a vector of characteristics of the public employees' retirement system in city $j, \alpha_{1}$ and $\alpha_{2}$ are vectors of coefficients, $\alpha_{0}$ is the intercept term, and $u_{j}$ is a random error term. Variants of Equation 4 are estimated in this section using 1973 cross-section data on police and firefighters in cities with populations greater than 50,000 . The data used in the analyses come Irom the micro data files underlying the U.S. Bureau of the Census, 1972 County and City Data Book (WashingIon, D.C.: G.P.O., 1973), and the International City Management Association, "1973 Survey of Personnel Policies in Muni-

\footnotetext{
loSee Sherwin Rosen, "Hedonic Prices and Implicit Markets," Joumal of Political Economy, Vol. 82, No. I (January-Felbruary 1974), pp. 94 -55. I should stress that I do consider the role of risk of nonpayment of benefits later in this paper. Recently, Robert $\mathbf{E}$. Lucas, "Hedonic Wage Equations and Psychic Wages in the Returns to School," American Economic Review, Vol. 67, No. 4 (September 1977), pp. 549-58, and Whiting, "Compensaling Wage Diflerentials," have utilized Rosen's approach to analyze the tradeofis between wages and nonpecuniary job characteristics and between private sector wages and pension plan characteristics.
}

cipal Police and Fire Departments."

The $X_{j}$ are drawn from those variables that have been shown to influence public sector wages in previous studies of public sector wage determination." "These include a measure of union power, the form of municipal government, and a set of sociodemographic and economic variables that represent the determinants of the fiscal capacity of a municipality, the relative preferences of a community for various public services, and alternative wages in the private sector. As with previous studies, the $X_{j}$ do not include any measures of the "quality" of municipal employees in a city; these data are unfortunately not available. To the extent that municipalities that offer high wages and generous retirement benefits can attract better applicants, and consequently higher quality employees, the omission of any "quality" variables may bias the estimates of the coefficients of the retirement system characteristics away from finding evidence of any compensating differentials.

The available retirement system characteristics in this first data set include whether police and firefighters belong to the same retirement system, whether the uniformed employees' retirement system is distinct from the system for other municipal employees, whether a compulsory retirement age exists, the minimum age an employee must attain to be eligible for regular retirement benefits, the percentage of salary that retirees receive for minimum regular retirement benefits, and the employees' retirement contributions as a fraction of their annual salary. While the lirst three retirement system characteristics are included primarily as controls, the latter three directly affect employers' net pension costs. It is straightforward to show that, ceteris paribus, an increase in the retirement age or the employees' contribution rate reduces em. ployers' net pension costs and an increase in the plan's generosity increases it. ${ }^{12}$

Listimates of variants of Equation 4 that utilize the logarithms of annual police patrolmen and firefighters' entrance $\left(W_{1}\right)$

\footnotetext{
11See, for example, the studies cited in footnote 8.

"rSee Barnow and Iinrenberg, "The Costs of De. fined Benefit ....".
} 
Table 1. The Impact of Retilement System Parameters on Uniformed Employees Earnings: All Systems."

(standard errors in parentheses)

\begin{tabular}{|c|c|c|c|c|c|c|c|c|}
\hline \multirow{2}{*}{$\begin{array}{l}\text { Independent } \\
\text { Variabiles }\end{array}$} & \multicolumn{3}{|c|}{ Police } & \multicolumn{5}{|c|}{ Finefighter } \\
\hline & $\mathbf{~} v_{1}$ & $W_{2}$ & $P V$ & $w_{1}$ & $w_{z}$ & $\hat{w}_{1}$ & $\hat{W}_{2}$ & $P^{\prime \prime}$ \\
\hline$x_{1}$ & $\begin{array}{c}-, 007 \\
(.017)\end{array}$ & $\begin{array}{c}-.031 .4 \\
(.018)\end{array}$ & $\begin{array}{c}-.000 \\
(.017)\end{array}$ & $\begin{array}{c}.020 \\
(.016)\end{array}$ & $\begin{array}{c}-.002 \\
(.017)\end{array}$ & $\begin{array}{c}.102 * \\
(.022)\end{array}$ & $\begin{array}{r}.07 y * \\
(.022)\end{array}$ & $\begin{array}{c}.007 \\
(.018)\end{array}$ \\
\hline$x_{2}$ & $\begin{array}{c}.029 \\
(.016)\end{array}$ & $\begin{array}{l}.0933^{* *} \\
(.018)\end{array}$ & $\begin{array}{l}.017 * \\
\{, 017\rangle\end{array}$ & $\begin{array}{r}.0977^{*} \\
(.017)\end{array}$ & $\begin{array}{r}.050^{\circ} \\
(.017)\end{array}$ & $\begin{array}{r}.083^{*} \\
(, 022)\end{array}$ & $\begin{array}{r}.0966^{*} \\
(.022)\end{array}$ & $\begin{array}{l}.094 * \\
(.017)\end{array}$ \\
\hline$x_{y}$ & $\begin{array}{r}.185^{\circ} \\
(.070\rangle)\end{array}$ & $\begin{array}{r}.210^{*} \\
(.074)\end{array}$ & $\begin{array}{l}.145 * \\
(.072)\end{array}$ & $\begin{array}{r}.18 \% * \\
(.070)\end{array}$ & $\begin{array}{l}.256^{*} \\
(.071)\end{array}$ & $\begin{array}{r}.26)^{*} \\
(.095)\end{array}$ & $\begin{array}{r}.930^{*} \\
(.093)\end{array}$ & $\begin{array}{r}.272^{*} \\
(.074)\end{array}$ \\
\hline$x_{t}$ & $\begin{array}{l}.107 * \\
(.039)\end{array}$ & $\begin{array}{c}.176^{*} \\
(.041)\end{array}$ & $\begin{array}{l}.183^{*} \\
(.039)\end{array}$ & $\begin{array}{l}.07 \% * \\
(.039)\end{array}$ & $\begin{array}{c}.088^{*} \\
(.099)\end{array}$ & $\begin{array}{c}.079 \\
(.059)\end{array}$ & $\begin{array}{l}.091^{* *} \\
(.051)\end{array}$ & $\begin{array}{l}.078^{4 *} \\
(.012)\end{array}$ \\
\hline$x_{5}$ & $\begin{array}{r}.352^{*} \\
(.055)\end{array}$ & $\begin{array}{l}.9010 \\
(.058)\end{array}$ & $\begin{array}{r}.921^{*} \\
(.056)\end{array}$ & $\begin{array}{c}.9814 \\
(.054)\end{array}$ & $\begin{array}{r}.279^{*} \\
(.054)\end{array}$ & $\begin{array}{r}.3164 \\
(.075)\end{array}$ & $\begin{array}{r}.211^{*} \\
(, 071)\end{array}$ & $\begin{array}{r}.28 .9 * \\
(.058)\end{array}$ \\
\hline$X_{f i}$ & $\begin{array}{r}.2866^{\circ} \\
(.065)\end{array}$ & $\begin{array}{c}.281 \\
(.069)\end{array}$ & $\begin{array}{r}.293 * \\
(.067)\end{array}$ & $\begin{array}{r}.370^{*} \\
(.067)\end{array}$ & $\begin{array}{r}.290^{\circ} \\
(.067)\end{array}$ & $\begin{array}{r}.920^{*} \\
(.050)\end{array}$ & $\begin{array}{r}.299^{\circ} \\
(.088)\end{array}$ & $\begin{array}{c}.282 * \\
(.072)\end{array}$ \\
\hline$x_{7}$ & $\begin{array}{c}\left..07\right|^{*} \\
(.0 \mid \mathrm{B})\end{array}$ & $\begin{array}{r}.089^{\circ} \\
(.019)\end{array}$ & $\begin{array}{l}.084^{*} \\
(.019)\end{array}$ & $\begin{array}{l}.05,10^{*} \\
(.017)\end{array}$ & $\begin{array}{c}.017 * \\
(.017)\end{array}$ & $\begin{array}{c}.011 \\
(.023)\end{array}$ & $\begin{array}{l}.001 \\
(.023)\end{array}$ & $\begin{array}{l}.054 * \\
(.019)\end{array}$ \\
\hline$x_{g}$ & $\begin{array}{c}.015 \\
(.009)\end{array}$ & $\begin{array}{r}.048^{\circ} \\
(.010)\end{array}$ & $\begin{array}{r}.012^{*} \\
(.010)\end{array}$ & $\begin{array}{l}.020 * \\
(.011)\end{array}$ & $\begin{array}{l}.024 * \\
(.011)\end{array}$ & $\begin{array}{c}.011 \\
(.04 t)\end{array}$ & $\begin{array}{c}.019 \\
(.01 \mathrm{~d})\end{array}$ & $\begin{array}{r}.023 * \\
(.011)\end{array}$ \\
\hline$x_{! !}$ & $\begin{array}{l}.01 t^{\circ} \\
(.000)\}\end{array}$ & $\begin{array}{l}.00)^{*} \\
(.000)\end{array}$ & $\begin{array}{c}.001^{\circ} \\
(.000)\end{array}$ & $.002 *$ & $\begin{array}{l}.001 \% \\
(.000)\end{array}$ & $\begin{array}{c}.009^{*} \\
(000)\end{array}$ & $\begin{array}{c}.002^{*} \\
(.000)\end{array}$ & $(.00 \%)$ \\
\hline$n_{1}$ & $\begin{array}{l}.050 * \\
(.018)\end{array}$ & $\begin{array}{c}.023 \\
(.019)\end{array}$ & $\begin{array}{c}.023 \\
(.019)\end{array}$ & $\begin{array}{c}.087 * \\
(.018)\end{array}$ & $\begin{array}{c}.032 \\
(.018)\end{array}$ & $\begin{array}{c}.019 \\
(.024)\end{array}$ & $\begin{array}{l}.013 \\
.02-1)\end{array}$ & $\begin{array}{c}.022 \\
(.020)\end{array}$ \\
\hline$n_{2}$ & $\begin{array}{c}.001 \\
(.02+1)\end{array}$ & $\begin{array}{c}-.008 \\
(.0 \mathrm{E} 5)\end{array}$ & $\begin{array}{c}.006 \\
(.023)\end{array}$ & $\begin{array}{r}.0 .904 \\
1.0206)\end{array}$ & $\begin{array}{c}.073 * \\
(.026)\end{array}$ & $\begin{array}{c}.085 * \\
(.035)\end{array}$ & $\begin{array}{r}.1000 \\
(.034)\end{array}$ & $\begin{array}{c}.078 * \\
(.028)\end{array}$ \\
\hline$n_{3}$ & $\begin{array}{r}-.0014 \\
(.001)\end{array}$ & $\begin{array}{c}-.009 \\
(.002)\end{array}$ & $\begin{array}{r}-.003^{*} \\
(.041)\end{array}$ & $\begin{array}{r}-.003^{*} \\
(0.001)\end{array}$ & $\begin{array}{c}-.005 * \\
(.001)\end{array}$ & $\begin{array}{c}-.003 \\
\{.002)\end{array}$ & $\begin{array}{c}-.002 \\
(.002)\end{array}$ & $\begin{array}{c}-.00 \% * \\
(.001)\end{array}$ \\
\hline$n_{1}^{b}$ & $\begin{array}{c}.0 ; 0 \\
(2<(9)\end{array}$ & $\begin{array}{c}.111 \\
(.215)\end{array}$ & $\begin{array}{c}.000 \\
(.008)\end{array}$ & $\begin{array}{c}.013 \\
(.187)\end{array}$ & $\begin{array}{c}-.147 \\
(.180)\end{array}$ & $\begin{array}{c}.131 \\
(.25 \cdot 4)\end{array}$ & $\begin{array}{c}-.009 \\
(.247)\end{array}$ & $\begin{array}{c}.001 \\
(.002)\end{array}$ \\
\hline
\end{tabular}

Definitionol variables:

$X_{1} \quad I=$ formal parity agreeneme for police and firefighters; $0=$ none

$x_{2} \quad l=$ wiges determined ly formal taion negotiations: $0=n 01$

$X_{\$} \quad$ logarithm of median family jucoute in 1969

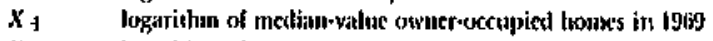

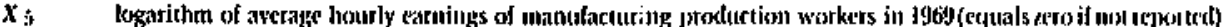

$X_{\text {if }} \quad I=$ average hourly sarnings not tepouted; $0=$ chlierwise

$\mathrm{X}_{3} \quad \mathrm{I}=$ city + manager lorm of govertment: $0=$ otherwise

$X_{\text {y }} \quad$ logarithm of 1969 jxpulation

$X_{4} \quad 1969$ poptothtion dens.jty

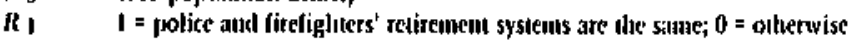

$\mathrm{H}_{2} \quad \mathrm{I}$ a compulsory tetiretacnt auge exists; 0 = otherwise

$R, \quad$ uniojinum age for regular tetitcmest in 1973

$\mathrm{N}_{\mathrm{A}} \quad$ minimum yeats survice for regular retirement in 1979

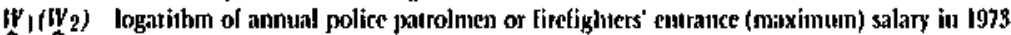

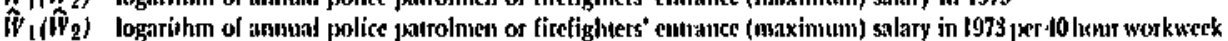

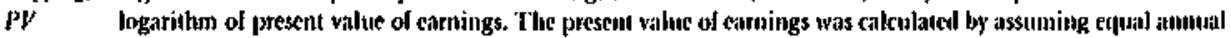

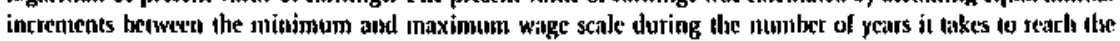
maximum in a city, a 25 year liorizon, and a $10 \%$ cliscoutut rate. The results were invastitut to choice of horizon (25)

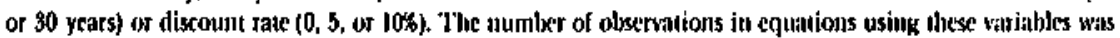
sminler than in other equations because sone cities did not report data on lhe number of years it takes to rearh their maximum salaries.

-Cocificient is signilicantly different Irom zeroat the ,05 lewel of significance with a two-tailed lest.

* Coclficient is significamty diflerent from zeroat the . 10 level of signilicance withatwo-lailed test. 
Table 1. (Continued)

\begin{tabular}{|c|c|c|c|c|c|c|c|c|}
\hline \multirow{2}{*}{$\begin{array}{l}\text { Indepentent } \\
\text { l'ariables }\end{array}$} & \multicolumn{3}{|c|}{ Police } & \multicolumn{5}{|c|}{ Firefighter } \\
\hline & $w_{1}$ & {$\left[v_{\underline{z}}\right.$} & $P^{\prime \prime}$ & $w_{1}$ & $\mathrm{JN}_{2}$ & $\hat{t}_{1}$ & $\hat{H}_{2}$ & $W^{\prime}$ \\
\hline$z_{t}^{b}$ & $\begin{array}{c}-.135^{* *} \\
(.078)\end{array}$ & $\begin{array}{r}-.171^{*} \\
(.082)\end{array}$ & $\begin{array}{c}-.097 \\
(.098)\end{array}$ & $\begin{array}{c}.085 \\
(.047)\end{array}$ & $\begin{array}{c}.067) \\
(.087)\end{array}$ & $\begin{array}{l}.157 \\
(.117)\end{array}$ & $\begin{array}{c}.191 \\
(.+114)\end{array}$ & $\begin{array}{c}.006 \\
(.099)\end{array}$ \\
\hline$R_{i j}$ & $\begin{array}{r}.063^{\circ} \\
(.025)\end{array}$ & $\begin{array}{r}.055 * \\
(.026)\end{array}$ & $\begin{array}{l}.06)^{*} \\
(.026)\end{array}$ & $\begin{array}{c}.010 \\
(.024)\end{array}$ & $\begin{array}{c}.012 \\
(.02 \mathrm{~A})\end{array}$ & $\begin{array}{c}-.001 \\
(.092)\end{array}$ & $\begin{array}{c}-.002 \\
\{.03 \mathrm{~d}\}\end{array}$ & $\begin{array}{c}.017 \\
(.026)\end{array}$ \\
\hline$n_{3}$ & $\begin{array}{l}.285^{*} \\
(.118)\end{array}$ & $\begin{array}{l}.317 * \\
(1.125)\end{array}$ & $\begin{array}{l}.907 n \\
(.117)\end{array}$ & $\begin{array}{l}1.2484 * \\
(.410\}\end{array}$ & $\begin{array}{l}1.65 \cdot 1 * \\
(.6+5)\end{array}$ & $\begin{array}{l}1.177 * \\
(.597)\end{array}$ & $\begin{array}{l}1.528 \% \\
(.581)\end{array}$ & $\begin{array}{l}1.794 \% \\
(.69 t 5)\end{array}$ \\
\hline$\overline{\mathrm{R}}^{2}$ & .723 & .27 & .733 & .712 & 717 & 658 & .66 & .715 \\
\hline n & 146 & 146 & 191 & 161 & $|6|$ & 161 & $\mid(6)$ & 143 \\
\hline
\end{tabular}

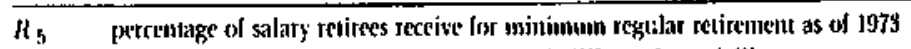

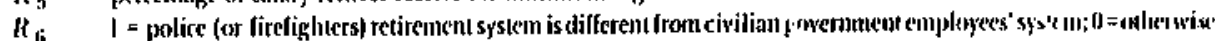

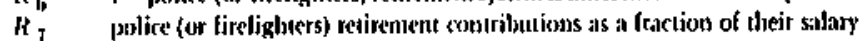

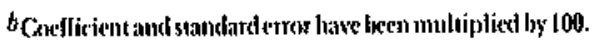

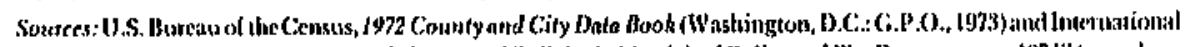

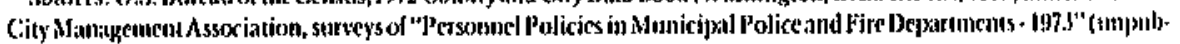
listed datai files).

and maximum $\left(W_{2}\right)$ salaries, the logarithms of firefighters' entrance $\left(\hat{W}_{1}\right)$ and maximum $\left(W_{2}\right)$ salaries per 40 hour workweek, and the logarithms of an estimate of the present value of police patrolmen and firefighters' annual carnings as dependent variables are presented in Table 1. Definitions and sources of all the variables are given in this table, which uses data from all cities over 50,000 that reported information on wages and retirement system characteristics. Table 2 presents the coefficients of the retirement system characteristics obtained from similar regressions restricted to a subset of cities in which the uniformed employees' retirement systems are distinct from the systems for other municipal employees.

The coeflicients of the $X_{j}$ variables found in Table $l$ are of interest in their own right and warrant brief discussion. A formal parity agrecment $\left(X_{1}\right)$ decreases the police annual wage, but leads to an increase in the lirefighter annual wage (standardized for hours of work). Firefighters' hourly wages are higher in cities with union contracts primarily because of the reduction in hours of work the unions have achieved (compare the coefficients of $X_{2}$ in columns 4 and 5 in Table 1 with those in columns 6 and 7). While annual wages are higher in cities in which a city manager is the chief operating officer $\left(X_{7}\right)$, the differential vanishes for
Cirefighters once we control for hours of work. These results are all consistent with previous studies of public secior wage determination, as are the coefficients of the other socioeconomic and demographic variables included in the analysis.

In the main, when significant the signs of the retirement system coefficients are as predicted. Increasing the fraction of their salaries that police and firefighters contribute to their retirement systems $\left(R_{7}\right)$ reduces municipal employers' net pension costs, celeris paribus, and does lead to an increase in their employees' wages. The results in Table 1 appear to indicate that firefighters are more successful than police in obtaining higher wages to compensate them for higher employee retirement contributions; however, once I restrict the sample to uniformed employee-specific systems (Table 2), their differential success vanishes. Indeed, ont can not reject the hypothesis that police and lirefighters are fully compensated for increased contributions (every one percentage point increase in their contribution rate leading to an increase in salaries of one percent) from these data.

As expected, increases in the percentage of salary police receive for minimum regular retirement $\left(R_{5}\right)$ do significantly reduce wages, but the relationship is insignificant for firefighters. In cities with a compulsory 
Table 2. The Impact of Retirement System Parameters on Uniformed Employees Earnings: Uniformed Employee-Specific Systems."

(standard errors in parentheses)

\begin{tabular}{|c|c|c|c|c|c|c|}
\hline \multirow{2}{*}{$\begin{array}{l}\text { Independent } \\
\text { Variables }\end{array}$} & \multicolumn{2}{|c|}{ Police } & \multicolumn{4}{|c|}{ Fivelighter } \\
\hline & $w_{1}$ & $w_{2}$ & $w_{1}$ & $w_{2}$ & $\hat{w}_{1}$ & $\hat{W}_{2}$ \\
\hline$R_{z}$ & $\begin{array}{c}.005 \\
(.026)\end{array}$ & $\begin{array}{c}-.014 \\
(.027)\end{array}$ & $\begin{array}{c}.050 * * \\
(.028)\end{array}$ & $\begin{array}{r}.066^{*} \\
\langle .028)\end{array}$ & $\begin{array}{c}.078^{*} \\
(.040)\end{array}$ & $\begin{array}{l}.093^{*} \\
(.099)\end{array}$ \\
\hline$R_{3}$ & $\begin{array}{r}-.004 * \\
(.002)\end{array}$ & $\begin{array}{c}-.002 \\
(.002)\end{array}$ & $\begin{array}{r}-.0024 \\
(.001)\end{array}$ & $\begin{array}{c}-.002 \\
(.002)\end{array}$ & $\begin{array}{c}-.003 \\
(.002)\end{array}$ & $\begin{array}{c}-.002 \\
(.002)\end{array}$ \\
\hline$R_{1}^{b}$ & $\begin{array}{c}-.077 \\
(.251)\end{array}$ & $\begin{array}{r}-.0066 \\
(.258)\end{array}$ & $\begin{array}{c}-.056 \\
(.199)\end{array}$ & $\begin{array}{c}-.223 \\
(.200)\end{array}$ & $\begin{array}{l}.090 \\
.(283)\end{array}$ & $\begin{array}{c}-.076 \\
(.275)\end{array}$ \\
\hline$R_{5}^{b}$ & $\begin{array}{c}-.120 \\
(.086)\end{array}$ & $\begin{array}{c}-.192^{*} \\
(.089)\end{array}$ & $\begin{array}{l}.113 \\
(.109)\end{array}$ & $\begin{array}{c}.193 \\
(.103)\end{array}$ & $\begin{array}{l}.212 \\
(.116)\end{array}$ & $\begin{array}{l}.232 \\
(.142)\end{array}$ \\
\hline$R_{\eta}$ & $\begin{array}{l}1.611^{*} \\
(.561)\end{array}$ & $\begin{array}{l}2.169^{*} \\
(.577)\end{array}$ & $\begin{array}{l}1.434^{*} \\
(.519)\end{array}$ & $\begin{array}{l}2.063^{*} \\
(.520)\end{array}$ & $\begin{array}{l}1.319 * * \\
(.739)\end{array}$ & $\begin{array}{l}1,912 * \\
(.718)\end{array}$ \\
\hline$\overline{\mathrm{R}}^{2}$ & .690 & .718 & .703 & .719 & .634 & .651 \\
\hline$n$ & 127 & 127 & 139 & 139 & 199 & 139 \\
\hline
\end{tabular}

a All of the variables included in 'Table 1 were also included in each equation but, for brevity, their coefficients are not reported here. See Table I for variable delinitions and source of data.

${ }^{b}$ Costlicient and standard errors have been multiplied by 100.

* Signiticant at 05 level with a two-tailed tesi.

* Signilicant at 10 level with a two-tailed test.

retirement age, firefighters' wages are higher. While not explicitly included in my model, this latter result is consistent with the view that employers gain from such work rules and hence are willing to pay for them. ${ }^{19}$

In contrast, the coefficient of the minimum regular retirement age variable $\left(R_{5}\right)$ is negative whenever it is statistically significant. At first glance, this result appears to be inconsistent with my model. Later retirenient ages reduce employers' net retirement system contributions, ceteris paribus, which should lead to compensatingly higher wages and a positive coefficient for this variable.

\footnotetext{
19 An alicrnative rationale for the relationship between mandatory retirement provisions and wages is found in Lazear, "Why Is There Mandatory Retire. ment?" Lazear's model implies that wage growth should be positively associated with the existence of mandatory retirement provisions. Since the estimated percentage effecls of mandatory retirement provj. sions on firelighters' maximum salaries is greater than that on minimum salaries (see Tables I and 2), some support for his view is tound here.
}

I should stress, however, that the implication that public employees' retirement age and wage scales will be positively correlated was derived from a model in which retirement systems were assumed to be fully funded and employers expected with certainty to make promised pinsion payments. In the next section, which considers the im. pact of underlunding on the wage-pension trade-off in more detail, I argue that if underfunding is meant to be "permanent" and is negatively correlated with the probability that promised retirement benefits will be lully paid rather than simply reflecting an intertemporal transfer of pension costs, then employers with more fully funded systems would pay lower wages, ceteris paribus. Elsewhere I have shown that holding other things constant, including employers' net contributions to the retirement fund, a higher retirement age will lead to a more fully funded retirement system. ${ }^{14}$ Hence, a

\footnotetext{
"Ronald G. Ehrenberg, "Correlates of Under. funding of Public Sector Retirement Systems," Eco. nomic Inquiry (forthcoming).
} 
negative relationship is generated between wages and retirement ages that may well offset the positive relationship predicted by the previous model. Thus, the negative relationship between retirement age and public sector wages observed in this section is not necessarily inconsistent with the existence of a trade-off jetween retirement system characteristics and wages. ${ }^{15}$ Additional empirical evidence to support the "funding" hypothesis is presented below.

\section{The Impact of Underfunding on the Wage-Pension Trade-Off}

The empirical results just presented are based upon a model in which public em. ployees expect to receive their promised pension benefits with certainty and in which public employers make sufficient contributions to retirement systems to keep the systems fully funded. Many public sector retirement systems are far from fully funded, however; the House Pension Task Force recently estimated that 75 percent of public employers were not funding at the levels required by ERISA and that the average lunding deficiency was about $\$ 16,000$ per worker. ${ }^{16}$ State constitutional guarantees of public employees' pension benefits notwithstanding, public employees may perceive that underfunding reduces the probability that they will receive some, or all, of their promised future retirement benefits. ${ }^{17}$ Consequently, they may demand

${ }^{15}$ The negative relationship may also arise because of simultansous equations bias, since malny of the lactors that influence wages may also influence retirement system parameters. A strong union, for example, could achieve both a high wage scale and a low minimtim retirement age, resulting in a spurious negative conrelation between the two variables. Un. fortunately. the available data are not rich enough to provide a set of variables that can be used to identify a structural system in which wage and reijrement system characteristics are simultaneously determined. This problem is discussed in more detail below.

16U.S. House of Representatives, Pension Task Force Report . .., pp. 88-89.

"See J. Richard Aronson, "Projections of State and Local Trust Fund Financing" in David Ott, et al., State and Local Finances in the Last Hall of the 1970's (Washington, D.C.: American Enterprise Institute, 1975); Alicia Munnell and Ann Connolly, "Funding Public Pensions: State-Local, Civil Service, and Military" mimeo (Federal Reserve Bank of Bosion, higher current wages as the extent of underfunding increases. Moreover, to the extent that public employers perceive their underfunding to be "permanent." and not merely a way of shifting retirement system costs on to future generations of taxpayers, their net retirement system contributions will decrease and they should be "willing" to pay higher wages. ${ }^{18}$ Thus, the extent of underfunding should be allowed to influence the magnitude of the public sector wage-pension benefits trade-off. ${ }^{19}$

October 1977) and Tilove, Public Employee Pension Funds, for a discussion of the funding problem. Although court decisions or constitutional requirements in some states (such as New York) Lorbid dimu. nition of pension rights, it is dillicult to see how these requirements are enforceable if state legislatures reluse to appropriate lunds, if some political jurisdictions shrink to the point that makes continual linancing of their retirement systems impossible, or if local governments also face statutory or constitutional limits on their tax rates or debt ratios. Indeed, Phillip Dearborn, Pensions for Police and Firemen (Washington, D.C.: Lalor Management Relations Service, 1974) notes that within the last fiften years, two cities-Hamutramack, Michigan, and Lakewood, Ohio-have been at times unable to make pension payments to retirees. Robert Tilove, Public Employee Pension Funds, and Aronson, "Projections of . . .." provide a more complete discussion of the possible relationship between underfunding of public relitement systems and retirement benelit security.

19This view of underfunding should be contrasted with that of Mumy, "The Economics of . ..." who treats underfunding as an intertemporal cost transfer, not as reflecting the probability of nonpayment of benefíts.

19The argument in the text warrants elaboration: the actual ellect of underfunding on wages depends upon both employers' and employees' perceptions, making a number of sicuations possible. First, employers may view underfunding as simply an intertemporal cost transfer. II this is the case, they would not be willing to offer higher wages in the event of underfunding and no wage-underlunding trade-off would be observed.

Second, employers may regard underfunding as cost saving, at least to the currently elected admin. istration. This might occur if they are unconcerned about future financial crises that may result (due to underfunding) after they leave oflice or if they believe higher levels of governmenı would "bail-out" their retirement system if relirees ever faced possible non. receipt of benefits. If undertunding reduces public employers' perceived costs ol pensions, this will increase their willingness to pay higher wages; whether a wage-underfunding irade-olf actually exists, however, depends on employees' perceptions.

If employees are unaware of underfunding or be. 
Unfortunately, accurate estimates of the extent of underfunding of individual public sector retirement systems are scanty. However, even when funding data are not di. rectly observable there is a way to "control" for the extent of underfunding in analyses of the trade-off. Elsewhere, I have presented a series of models of public sector retirement systems and for each derived the observable determinants, or correlates, of the extent of retirement system funding. ${ }^{20}$ Ceteris paribus, the extent of retirement system funcl. ing is seen in these models to vary directly with the ratio of retirement system assets to current benefit payments, the ratio of the number of local government employees to the number of retirees receiving benefits, the ratio of the fraction of wages paid into the system by the employer and employees to the fraction of final wages received as retirement benelits by retirees, with the real rate of return on retirement system assets, and with the retirement age. Hence, as each of these variables incrcases one would expect to observe public employees' wages decreasing if, in fact, the extent of funding is related to the probability of receipt of promised retirement benefits.

'The negative relationship between the retitement age and wages observed in the previous section may well reflect the correlation of the former with the extent of underfunding. More confidence could be placed

lieve it will have no effect on their expeciel retirement benefits, hey will ignore underfunding in their choice of employers and, ceteris paribus, be attracted to high-wage employers. Since employers who tunderfund could (in the alove case) alford to pay ligher wages, onte would expect to observe large-scale underfunding predominating, as employers sottght to pay high wages to attract municipal employees. In other worts, one might observe near total underfunding by all public enployers and no wage-underfunding trade. oft.

If employess are awate of underfunding, however, and if they perceive in to reduce their expecied bentits, they would demand higher wages to compensate then for the risks associated with underfunding. Enployers with unfunded retirement systems would have to offer higher wages to attract employees; thus, as tIIn. fended liabilities increased so would wages. Only in this situation, the one I focus on in the text, would one observe both a positive wage-underfunding tradeoff and the coxxistence of retirement systems in which funding practices vary widely.

20See Ehrenberg, "Correlates of Underfunding ...". in this interpretation if the other correlates were also shown to influence public sector wages. Fortunately, data on them are available from the U.S. Bureau of the Census (1974) for a subset of the retirement systems in my sample. These data were merged with data from the two previous sources, thus permitting estimation of equations of the form

$$
\begin{aligned}
W_{i j}= & \alpha_{0}+\alpha_{1} X_{j}+\alpha_{2} R_{j} \\
& +\alpha_{3} F_{j}+u_{j},
\end{aligned}
$$

where $F_{j}$ represents the vector of observable correlates of the extent of retirement system underfunding, other than the retirement age. Estimates of the coefficients of these correlates $\left(F_{j}\right)$ are found in Table 3 .

Perhaps due to the relatively small sample sizes, the coefficients tend to be statistically insignificantly different from zero. ${ }^{21}$ When significant, however, they have the correct sign. An increase in the estimated rate of return on assets $\left(F_{2}\right)$ does tend to reduce wages, while an increase in the ratio of retired system members to active system members $\left(F_{3}\right)$ does tend to increase wages, ${ }^{22} \mathrm{Sim}$ ilarly, an increase in annual benefits paid to each retired member in relation to the sys. tem's annual receipts per active member $\left(F_{s}\right)$ does tend to increase firefighters' wages as predicted. Each of these results is consistent with what we would expect if these variables were correlates of the extent of system under. lunding.

While the results of this section are not totally unambiguous, they do support the view that these correlates are useful proxies for the extent of retirement system underfunding. Furthermore, the extent of underfunding does appear to be related to employers' (and employees') perceptions of the probability that promised retirement benelits will not be fully paid, and these perceptions are reflected in compensating wage differentials. ${ }^{23}$

\footnotetext{
${ }^{21}$ The inclusion of the funding variables $(F)$ and the stnatl sanuple sizes caused many of the coellicients of the retirement system variables $(R)$ to become insignificant. However, those that remained statistically signilicant luad the same signs as they did in Table I.

${ }^{2}$ The data unforlunately did not permit me to include unrealized capital gains in $F_{2}$.

${ }^{25}$ Elsewhere, my colleague, Robert $S$. Smith has
} 
Table 3. The Impact of Retirement System Parameters on Uniformed Employees Earnings: Extent of Funding Coelficients.?

(standard errors in parentheses)

\begin{tabular}{|c|c|c|c|c|c|c|}
\hline \multirow{2}{*}{$\begin{array}{l}\text { Independent } \\
\text { Variableb }\end{array}$} & \multicolumn{2}{|c|}{ Potist } & \multicolumn{4}{|c|}{ Firefighter } \\
\hline & $w_{1}$ & $W_{2}$ & {$\left[r_{t}\right.$} & $\mathrm{I}_{2}$ & $\hat{H}_{1}$ & $\hat{W}_{2}$ \\
\hline
\end{tabular}

\begin{tabular}{|c|c|c|c|c|c|c|}
\hline \multicolumn{7}{|c|}{ Al] Systems } \\
\hline $\mathrm{j}_{1}$ & $\begin{array}{c}.016 \\
(.065)\end{array}$ & $\begin{array}{l}-.200 \\
(.058)\end{array}$ & $\begin{array}{c}.083 \\
(.050)\end{array}$ & $\begin{array}{c}-.045 \\
(.050)\end{array}$ & $\begin{array}{c}.053 \\
(.063)\end{array}$ & $\begin{array}{c}-.075 \\
(.067)\end{array}$ \\
\hline $\mathrm{F}_{2}{ }^{\mathrm{C}}$ & $\begin{array}{c}.003 \\
(.005)\end{array}$ & $\begin{array}{l}-.003 \\
(.00+1)\end{array}$ & $\begin{array}{c}-.016 \\
(.018)\end{array}$ & $\begin{array}{c}-.034 * * \\
(.0+8)\end{array}$ & $\begin{array}{c}.024 \\
(.022)\end{array}$ & $\begin{array}{c}.005 \\
(.024)\end{array}$ \\
\hline is & $\begin{array}{c}.051 \\
(.040)\end{array}$ & $\begin{array}{c}-.022 \\
(.095)\end{array}$ & $\begin{array}{l}.293^{*} \\
(.122)\end{array}$ & $\begin{array}{l}.214 * * \\
(.121)\end{array}$ & $\begin{array}{l}.34]^{*} \\
(.151)\end{array}$ & $\begin{array}{l}.262^{* *} \\
(.16 t)\end{array}$ \\
\hline $\mathrm{Ji}_{+}^{\mathrm{r}}$ & $\begin{array}{c}.065 \\
(.0+9)\end{array}$ & $\begin{array}{c}-.010 \\
(.430)\end{array}$ & $\begin{array}{c}-.054 \\
(.048)\end{array}$ & $\begin{array}{c}-.042 \\
(.048)\end{array}$ & $\begin{array}{c}-.059 \\
(.060)\end{array}$ & $\begin{array}{c}-.017 \\
(.061)\end{array}$ \\
\hline$r_{3}$ & $\begin{array}{c}.005 \\
(.018)\end{array}$ & $\begin{array}{c}-.026 \\
(.016)\end{array}$ & $\begin{array}{c}.005 \\
(.018)\end{array}$ & $\begin{array}{c}-.0 ! 6 \\
(.018)\end{array}$ & $\begin{array}{c}.050^{*} \\
(.022)\end{array}$ & $\begin{array}{c}.030 \\
(.023)\end{array}$ \\
\hline $\mathrm{n} / \mathrm{DO}]^{i}$ & $66 / 11$ & $66 / 11$ & $75 / 50$ & $75 / 50$ & $75 / 50$ & $75 / 50$ \\
\hline \multicolumn{7}{|c|}{ Unifoumcd limployer Specifjc Systems } \\
\hline$F_{1}$ & $\begin{array}{c}.350 \\
(.250)\end{array}$ & $\begin{array}{c}.110 \\
(.160)\end{array}$ & $\begin{array}{c}.084 \\
\{.076\}\end{array}$ & $\begin{array}{c}-.075 \\
(.077)\end{array}$ & $\begin{array}{c}.081 \\
(.104)\end{array}$ & $\begin{array}{c}-.076 \\
\left(.11^{\prime}\right)\end{array}$ \\
\hline $\mathbf{F}_{2}{ }^{r}$ & $\begin{array}{r}-.006 \\
(.018)\end{array}$ & $\begin{array}{c}-.012 \\
(.018)\end{array}$ & $\begin{array}{c}-.020 \\
(.018)\end{array}$ & $\begin{array}{r}-.0111^{*} \\
(.018)\end{array}$ & $\begin{array}{c}.019 \\
(.025)\end{array}$ & $\begin{array}{c}-.002 \\
(.0127)\end{array}$ \\
\hline$r_{3}$ & $\begin{array}{l}.105^{*} \\
(.135)\end{array}$ & $\begin{array}{l}.058 * 1 * \\
(.13 \cdot 4)\end{array}$ & $\begin{array}{l}.290^{*} \\
(.127)\end{array}$ & $\begin{array}{l}.250^{* *} \\
1 .(28)\end{array}$ & $\begin{array}{l}.319 * * \\
(.172)\end{array}$ & $\begin{array}{c}.260) \\
(.187)\end{array}$ \\
\hline $\mathrm{F}+$ & $\begin{array}{c}-.207 \\
(.352)\end{array}$ & $\begin{array}{c}-.069 \\
(.3+9)\end{array}$ & $\begin{array}{c}-.087 \\
(.177)\end{array}$ & $\begin{array}{r}-.062 \\
(.178)\end{array}$ & $\begin{array}{c}-.011 \\
(.02: 1)\end{array}$ & $\begin{array}{c}-.086 \\
(.260)\end{array}$ \\
\hline$r_{3}$ & $\begin{array}{c}.013 \\
(.018)\end{array}$ & $\begin{array}{c}-.024 \\
(.01 B)\end{array}$ & $\begin{array}{c}.008 \\
(.017)\end{array}$ & $\begin{array}{c}-.010 \\
(.01 B)\end{array}$ & $\begin{array}{r}.049^{*} \\
(.024)\end{array}$ & $\begin{array}{c}.030 \\
(.026)\end{array}$ \\
\hline $\mathrm{n} / \mathrm{DOF}$ & $53 / 2 \mathrm{y}$ & $53 / 29$ & $62 / 38$ & $62 / 38$ & i2/3it & $62 / 38$ \\
\hline
\end{tabular}

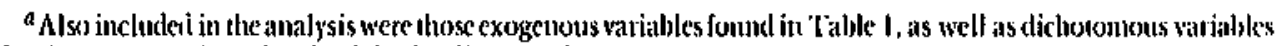
for the nonreporting of each of the funding proxies.

$t$ Definitions of F varialsles:

$F_{1}=$ propoltion of the detirement systemts members covered by the social sccurity system in 1977

$F_{2}=$ retirement system's realized eannings on investinents divided by the retirement system's asss'ts in 1971

$F_{3}=$ retirement systen's retired ineonbers divided by its aclive menulers in 1971

$F_{+}=$retirement system's assets divided by retirement system's antual bene[it payaneme in [07]

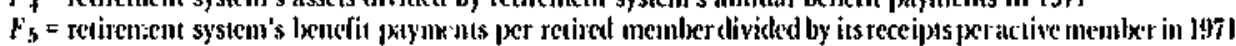

'Coelficient muliplied by 100.

* Siguilicatat at the 05 level witla a two-tailed test.

**Significant at the .10 level with at two-tailed test.

Source: U.S. Burean of the (iensus, 1972 Census of Goverments, Vol. 6, No, l, Employes Retirement Systems of State and Local Governments (Washingion, D.C.: G.P.O., 1973).

presented some more direct evidence on the tratc-off between the extent of underfunding and municipal employees' wage rates in Penusylvania. Sec Robert $S$. Souith, "Pensions, Underlunding, and Wages in the Public Sector" numeo (Cornell University, March 1979).

\section{Empirical Analysis: 1974 - 75 Survey Data}

The data analyzed in the previous two sections, although supportive of the view that a trade-off exists between public sector wages and retirement system characteristics, 
contain information on only a limited set of retirement system characteristics, none of which would likely be affected by public sector pension relorm legislation. Moreover, the data are restricted to police and firefighters. No information for other functional categories of employees is $\mathrm{p}$ esented.

To remedy these shortcomings, I now present analyses of data from the International Cily Management Association's 1774- 75 Survey of U.S. Municipality Em. ployee Benefils (see U.S. Conference of Mayors, Third National Survey . ..., for a description). These data have the advantagts of containing a large number of observations, covering sanitation employees as well as police and firefighters, and containing information on a much richer sel of retirement system characteristics. Their disadvantages are that they do not contain data on either unionization or employees' contributions to the retirement system and that they contain data on average annual earnings, rather than minimum and maximum wage scales. Average earnings may differ across cities because of differences in the seniority structures of the cities' work forces, and the omission of important explanatory variables, such as unionization and employee contributions, may bias the remaining coefficients. Nevertheless, because of the richer set of retirement system characteristics available, these data are a useful supplement to those analyzed in the previous section.

Table 4 presents estimates of variants of Equation 4 that utilize these data for a sample of cities over 25,000 in population for which data on the vector of variables $X$ were available. Also included in the table in brackets are the implied coefficients from a canonical correlation analysis; I will return to these latter coefficients shortly. Unam. biguous implications about the signs of several of the retirement system coefficients can be drawn and these are the variables upon which the discussion will center.

Unlike with the earlier data, increases in the minimum regular retirement age $\left(r_{3}\right)$ are significantly positively related to wages for both police and firefighters here, as predicted. When overlime pay is included in average salary used to calculate retire- ment benefits $\left(r_{9}\right)$, it increases employers' net costs of providing pensions and should thus reduce wages. This in fact occurs for firefighters. Similarly, if the calculation of retirement benefits uses a higher percentage multiple for earnings above a fixed level $\left(r_{10}\right)_{1}$ this should increase retirees' benefits and employers' costs, ceteris paribus, and reduce wages-which occurs for police. The existence of monthly deferred vested retirement benefits for individuals who leave service prior to retirement $\left(r_{13}\right)$ also in. creases employers' costs of pensions and should, and does, lead to lower wages. All these results are consistent with the existence of a trade-off between wages and retirement system characteristics.

In contrast, many retirement system characteristics one would expect to influence wage levels prove consistently to be insig. nificant. For example, in a period of inflation, or if wages increase with age, the smaller the number of years' salary used in the calculation of $W^{*}$, the higher retirement benefits and employers' costs will be and hence the lower wages should be. Relative to the omitted category ( $W^{*}$ equal to the Iinal year's wage), the coefficients of $r_{7}\left(W^{*}\right.$ equal to a 3- or 5-year average) and $r_{8}\left(W^{*}\right.$ equal to a 10 -year or career average) should therefore be positive. While in the main they are, the coefficients are never significant. Similarly, postretirement cost-of-living adjustments in retirement benefits should increase employers' net pension costs and lead them to pay lower wages. Yet coefficients of that variable are all insignificant and as a result the variable does not even appear in Table 4. Finally, the fraction of average pay retirees receive for normal retirement $\left(r_{11}\right)$ i: never significant. ${ }^{24}$

The insignificant coefficients of these retirement system characteristics may be due to collinearity among the various characteristics. What is more disturbing is that increasing the number of years of service required for regular retirement $\left(r_{4}\right)$ leads to $a$ reduction in wages, and the existence of

"The equations reported in Table 1 use fractions of pay alter 25 years of service. Substitution of the Iractions after 15 or 35 years, or use ol all three fractions simultancously does not alter this conclusion. 
Table 4. The Impact of Retirement System Parameters on the Average Earnings of Uniformed Employees: 1975 Survey Data. ${ }^{a}$ (standard errors in parentheses)

\begin{tabular}{|c|c|c|c|c|c|c|c|c|}
\hline \multirow{2}{*}{$\frac{\text { Variables }}{\mathrm{x}_{8}}$} & \multicolumn{2}{|c|}{$\boldsymbol{p}$} & \multicolumn{2}{|c|}{$\boldsymbol{F}$} & \multicolumn{2}{|c|}{ FA } & \multicolumn{2}{|c|}{$s$} \\
\hline & $\begin{array}{l}.031 * \\
(.014)\end{array}$ & {$[.154]^{b}$} & $\begin{array}{r}.050^{*} \\
(.012)\end{array}$ & {$[$ [262] } & $\begin{array}{l}.053^{*} \\
(.022)\end{array}$ & {$[.390]$} & $\begin{array}{c}.028 \\
(.024)\end{array}$ & [.189] \\
\hline$x_{1 j}{ }^{c}$ & $\begin{array}{c}.001 * \\
(.000)\end{array}$ & [.291] & $\begin{array}{l}.002^{*} \\
(.000)\end{array}$ & {$[.315]$} & $\begin{array}{l}.002 * \\
(.080)\end{array}$ & {$[.485]$} & $\begin{array}{c}.001 \\
(.000)\end{array}$ & $|.281|$ \\
\hline$x_{3}$ & $\begin{array}{l}.816^{*} \\
(.115)\end{array}$ & {$[.029]$} & $\begin{array}{l}.161^{* * *} \\
(.096)\end{array}$ & {$[.022]$} & $\begin{array}{c}.213 \\
(.179)\end{array}$ & {$[.403]$} & $\begin{array}{c}-.075 \\
(.184)\end{array}$ & [.672] \\
\hline$x_{1}$ & $\begin{array}{r}.218^{*} \\
(.073)\end{array}$ & {$[., 890]$} & $\begin{array}{r}.221 * \\
(.062)\end{array}$ & {$[.622]$} & $\begin{array}{l}.215^{* *} \\
(.110)\end{array}$ & [1.296] & $\begin{array}{l}.277^{*} \\
(.115)\end{array}$ & [1,839] \\
\hline$x_{3}$ & $\begin{array}{l}.283^{4} \\
\text { (.081) }\end{array}$ & [1.094] & $\begin{array}{r}.8529 \\
(.067)\end{array}$ & [1.008] & $\begin{array}{c}.075 \\
\text { (.121) }\end{array}$ & [.892] & $\begin{array}{l}.249 * * \\
(.139)\end{array}$ & [2.197] \\
\hline$x_{6}$ & $\begin{array}{r}.293 * \\
(.091)\end{array}$ & [1.002] & $\begin{array}{r}.963 * \\
(.976)\end{array}$ & {$[.925]$} & $\begin{array}{c}.054 \\
(.136)\end{array}$ & [.862] & $\begin{array}{l}.2850 * \\
(.148)\end{array}$ & [2.050] \\
\hline$x_{1}$ & $\begin{array}{c}.041 \\
(.028)\end{array}$ & {$[.059]$} & $\begin{array}{r}.052^{*} \\
(.022)\end{array}$ & $|.110|$ & $\begin{array}{c}.052 \\
\text { (.04I) }\end{array}$ & $|.216|$ & $\begin{array}{c}.041 \\
\{.043)\end{array}$ & {$[.007]$} \\
\hline$v_{1}$ & $\begin{array}{c}-.096 \\
(.028)\end{array}$ & [.197] & $\begin{array}{c}-.025 \\
(.022)\end{array}$ & {$[.075]$} & $\begin{array}{c}-.022 \\
(.039)\end{array}$ & {$[.194]$} & $\begin{array}{c}-.078^{\circ *} \\
(.045)\end{array}$ & [. [. \\
\hline$r_{2}$ & $\begin{array}{c}.051 \\
(.026)\end{array}$ & $(.131)$ & $\begin{array}{c}.008 \\
(.021)\end{array}$ & {$[.042]$} & $\begin{array}{c}.024 \\
(.038)\end{array}$ & {$[.116]$} & $\begin{array}{c}-.084 \\
(.042)\end{array}$ & [.274] \\
\hline $\mathrm{r}^{\mathrm{c}}$ & $\begin{array}{l}.189 * * * \\
(.113)\end{array}$ & {$[.173]$} & $\begin{array}{r}.215 * \\
(.092)\end{array}$ & (.205) & $\begin{array}{c}.252 \\
(.166)\end{array}$ & [.,10.t] & $\begin{array}{c}-.094 \\
(.184)\end{array}$ & $|-.207|$ \\
\hline$r_{4}^{r}$ & $\begin{array}{r}-.324^{*} \\
(.155)\end{array}$ & $|-.1| c \mid$ & $\begin{array}{r}-.501 * \\
(.129)\end{array}$ & {$[-.182\}$} & $\begin{array}{r}-.505^{*} \\
(.299)\end{array}$ & {$[-.017]$} & $\begin{array}{c}-.010 \\
(.198)\end{array}$ & $1.219 ;$ \\
\hline $\mathrm{I}_{5}$ & $\begin{array}{c}.002 \\
(.002)\end{array}$ & {$[.002]$} & $\begin{array}{c}.001 \\
(.002)\end{array}$ & {$[-.007]$} & $\begin{array}{c}.004 \\
(.003)\end{array}$ & {$[.075]$} & $\begin{array}{c}-.000 \\
(.002)\end{array}$ & [.120] \\
\hline$r_{6}$ & $\begin{array}{c}.0000 \\
(.003)\end{array}$ & {$[.092\}$} & $\begin{array}{c}-.001 \\
(.002)\end{array}$ & $\{.058\}$ & $\begin{array}{c}.002 \\
(.001)\end{array}$ & {$[.237]$} & $\begin{array}{c}-.005 \\
\{.006\}\end{array}$ & {$[.05 \mathrm{~B}]$} \\
\hline$r_{7}$ & $\begin{array}{c}.062 \\
(.033)\end{array}$ & {$[.104]$} & $\begin{array}{c}.022 \\
(.026)\end{array}$ & {$[.007]$} & $\begin{array}{c}.095 \\
(.047)\end{array}$ & {$[.162\}$} & $\begin{array}{c}-.007 \\
(.074)\end{array}$ & [.0k3] \\
\hline$r_{8}$ & $\begin{array}{c}.038 \\
(.085)\end{array}$ & [.269] & $\begin{array}{c}.022 \\
(.028)\end{array}$ & {$[.179]$} & $\begin{array}{c}-.057 \\
(.051)\end{array}$ & [.299] & $\begin{array}{c}.047 \\
(.078)\end{array}$ & [.82:5] \\
\hline
\end{tabular}

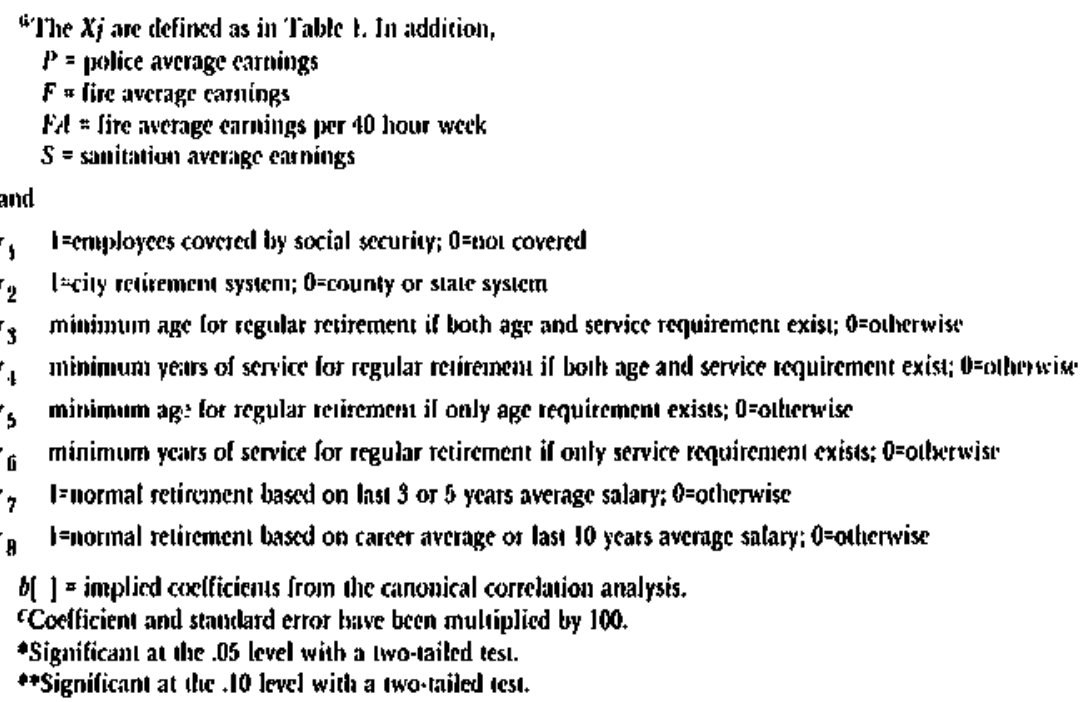


Table 4. (Continued)

\begin{tabular}{|c|c|c|c|c|c|c|c|c|}
\hline \multirow{2}{*}{$\frac{\text { I'nrimbiles }}{I_{9}}$} & \multicolumn{2}{|c|}{$p$} & \multicolumn{2}{|c|}{$F$} & \multicolumn{2}{|c|}{$F A$} & \multicolumn{2}{|c|}{$s$} \\
\hline & $\begin{array}{c}-.029 \\
(.026)\end{array}$ & {$[.000]$} & $\begin{array}{r}-.067^{*} \\
(.021)\end{array}$ & {$[-.103]$} & $\begin{array}{c}-.0677^{* *} \\
(.038)\end{array}$ & {$[1,010]$} & $\begin{array}{c}-.019 \\
(.012)\end{array}$ & $\{.170\}$ \\
\hline$t_{10}$ & $\begin{array}{c}-.082^{6 *} \\
(.012)\end{array}$ & {$[-.0991$} & $\begin{array}{c}.013 \\
(.032)\end{array}$ & $|.086|$ & $\begin{array}{c}.039 \\
\{.058)\end{array}$ & {$[.008]$} & $\begin{array}{c}-.052 \\
(.05 v)\end{array}$ & [0.0] \\
\hline$r_{11}$ & $\begin{array}{c}-.016 \\
(.057)\end{array}$ & $\mid-.025]$ & $\begin{array}{c}-, 0.16 \\
(.047)\end{array}$ & $\{-, 010\}$ & $\begin{array}{c}-.071 \\
(.086)\end{array}$ & {$[017]$} & $\begin{array}{l}.071 \\
(.068)\end{array}$ & [.006] \\
\hline$r_{12}$ & $\begin{array}{c}.00 \% \\
(.034)\end{array}$ & {$[-.066]$} & $\begin{array}{c}.051^{\text {** }} \\
(.027)^{2}\end{array}$ & {$[.050]$} & $\begin{array}{c}.022 \\
(.018\}\end{array}$ & {$[-.078]$} & $\begin{array}{c}.062 \\
(0.53)\end{array}$ & $\{.512\}$ \\
\hline$r_{1, s}$ & $\begin{array}{c}-.044 \\
(.02 \mathrm{~d})\end{array}$ & $1-.080]$ & $\begin{array}{c}-.093) \\
(.020)\end{array}$ & {$[-.073]$} & $\begin{array}{r}.0 .076^{*} \\
(.056)\end{array}$ & {$[-. \mid 52]$} & $\begin{array}{r}-.09 ; * \\
(0,0 \mid 2)\end{array}$ & $\{.0015\}$ \\
\hline$T_{1.1}$ & $\begin{array}{c}.055^{* * *} \\
(.031)\end{array}$ & [.I4I] & $\begin{array}{c}.014 \\
(.025)\end{array}$ & [.016] & $\begin{array}{c}.043 \\
(.055)\end{array}$ & $\left\{, 00^{\prime} 3\right\}$ & $\begin{array}{c}.002 \\
(.0415)\end{array}$ & $\left.\mid .2 t t_{0}\right]$ \\
\hline $\mathrm{T}_{\mathbf{H} \mathrm{S}}$ & $\begin{array}{r}.051)^{*} \\
(.028)\end{array}$ & {$[-.017]$} & $\begin{array}{c}.022 \\
(.022)\end{array}$ & {$[-.055]$} & $\begin{array}{c}-.023 \\
(.010)\end{array}$ & $[-.38]]$ & $\begin{array}{c}-.046 \\
(.043)\end{array}$ & {$[-.180]$} \\
\hline$r_{16}$ & $\begin{array}{c}.050 \\
(.085)\end{array}$ & {$[.2016]$} & $\begin{array}{c}.103 \\
(.078)\end{array}$ & {$[.255]$} & $\begin{array}{c}-.024 \\
(.195)\end{array}$ & {$[.045]$} & $\begin{array}{c}.023 \\
(.109)\end{array}$ & [.46is] \\
\hline$t_{17}$ & $\begin{array}{c}.069 \\
(.115)\end{array}$ & [.001] & $\begin{array}{l}.170 \\
(.138)\end{array}$ & {$[.076]$} & $\begin{array}{c}-.117 \\
(.218)\end{array}$ & {$[-.108]$} & $\begin{array}{c}.161 \\
(.227)\end{array}$ & [.207] \\
\hline$\overline{\mathbf{R}}^{2}$ & .521 & & .623 & & .301 & & .195 & \\
\hline " & $2 \leqslant 2$ & & 2512 & & $2 k i \%$ & & 157 & \\
\hline
\end{tabular}

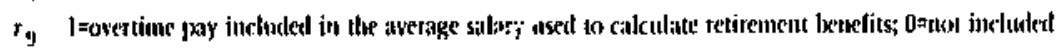

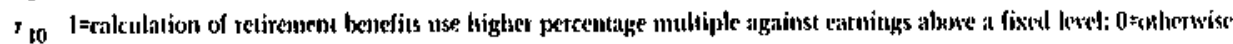

$7_{\text {II }}$ I=retirement Ienclits are seciased by social sccurity; $0=$ =sulherwise'

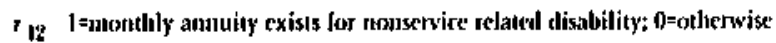

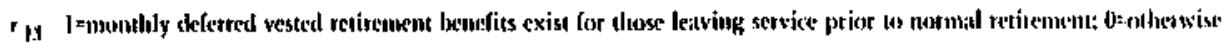

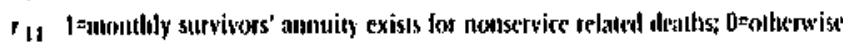

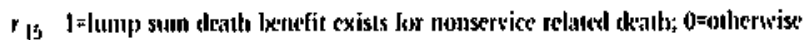

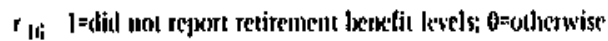

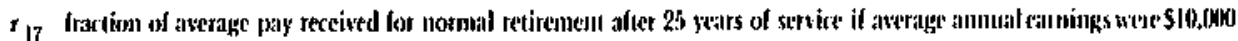

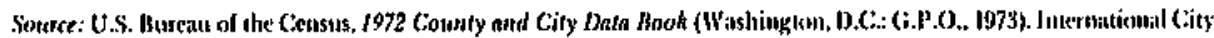

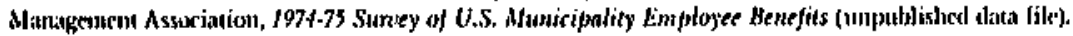

cither monthly survivors' benelits $\left(r_{14}\right)$ or lump-sum death benelits $\left(r_{15}\right)$ for nonservice-relatel deaths leads to an increase in wages. Each of these variables' ellects is opposite in sign to my prior expectation, based upon knowledge of their effects on employers' net pension costs.

It is of course possible that these param. eter estimates are subject to simultaneous equations bias; many of the exogenous factors that influence wages may also influence the relirement system characteristics. In the absence of a data set that is sufficiently rich to provide a set of variables that can be used to identify a structural system in which wages and retirement system characteristics are simultaneously determined, I adopt a second-best approach to try to control for this problem. Recall that we are estimating variants of Equation 4 and the statistical problem is that the vector $R_{j}$ may be corre. lated with the error term $u_{j}$. Now it Equa. tion 4 holds, it must be true that

$$
\begin{gathered}
\left(W_{i j}-\bar{W}_{i}\right)-\alpha_{2}\left(R_{j}-\bar{R}\right)= \\
\alpha_{1}\left(X_{j}-\bar{X}\right)+u_{j}
\end{gathered}
$$

where the bars indicate the mean values of the variables in the sample.

In this form, the vectors of parameters $\alpha_{1}$ and $\boldsymbol{\alpha}_{2}$ can be estimated using canonical correlation analysis. Since the wage and retirement system characteristic variables are now on the "same side" of the equation, simultaneous equations bias should be climinated. Moreover, as the parameters from canonical correlation analyses are unique only up to a multiple, we can normalize the resulting coefficients, setting the 
parameter of the deviation of the logarithm of earnings from its sample mean $\left(W_{i j}-\right.$ W) equal to one so as to make the other coefficients comparable to the regression coefficients found in Table 4. Although there are no significance lests for individual co. efficients in canonical correlation analysis comparable to the $t$-tests of regression analysis, and the coeflicients in this analysis cannot be given any structural interpretation, the magnitudes of the corresponding coefficients should suggest whether the estimates in Table 4 were subject to simultaneous equations bias.

The bracketed coefficients in Table 4 are the implied coefficients from the canonical correlation analyses that correspond to the regression coufficients. The coefficients have been normalized by setting the wage coefficient equal to one and the signs reported as if all variabies other than the wage variable were on the right-hand side of the equation. In the main, when the retirement system variables were statistically signilicant and of the correct sign before $\left(r_{3}, r_{9}\right.$, $r_{10}$ and $r_{13}$ ), the corresponding coeflicient from the canonical correlation analyses is of approximately the same magnitude and of the same sign. In contrast, several of the retirement system characteristics coefficients that were statistically significant and of the wrong sign belore now are smaller in absolute value $\left(r_{4}\right)$ or actually change sign $\left(r_{15}\right)$. These results suggest that the coefficients in Table 4 that had signs that 1 did not expect may well have been subject to simultaneous equations bias. However, until a richer data set that allows one to build a more complete model becomes available, no definitive conclusions can be reached on this point.

\section{Concluding Remarks}

The results presented in this paper sup. port the proposition that, holding other variables constant, increases in uniformed employees' retirement system contributions lead to compensating increases in their salaries. They also support the hypothesis that, other things equal, more "generous" retirement system parameters are associated with salaries for police and firefighters that, if not completely compensating, are at least lower than would otherwise be $\mathrm{cx}$. pected. Finally, they provide support for the view that the extent of retirement system underfunding is related to employers' and employees' perceptions of the proba. bility that promised retirement benefits will not be fully paid, and that these perceptions are reflected in compensating wage differentials. The evidence on the latter two points, however, is not totally unambig. uous.

Unfortunately, the retirement system parameters most likely to be affected by a public sector variant of ERISA (vesting rules, funding requirements, and standards for fiduciary responsibility) were not re. ported in the several data sets used in this paper. Hence, one cannol directly translate my results into delinitive quantitative statements about the effects of any proposed public sector pension reform legislation. Nevertheless, my results do support the proposi. tion that a trade-olf exists between wages and retirement system characteristics in the public sector and suggest that such legislation will likely have an impact on future levels of public sector wages. To the extent that fully compensating wage differentials do not exist, such legislation will also have. an impact on public sector employment levels and the taxes needed to finance state and local public services.

Clearly, additional studies should be undertaken in the future to imptove the precision of my estimates of the trade-off, hopefully using data sets that permit one to establish parameters for retirement systems in a manner amenable to policy simula. tions. ${ }^{25}$ If better data sets become available, one could ideally include other nonwage compensation items in the analysis and also estimate the wage-nonwage compensation trade-off in the context of a more complete structural model of the implicit market for nonwage compensation, as discussed in Sherwin Rosen's "Hedonic Price..." paper,

${ }^{25}$ Robert S. Sinith and 1 had hoped to analyze the clata that underly U.S. House of Representatives, Pemsion Task Force Repont, which contain unpullished information on funding and vesting provisions. Unfortunately, the House Sulicommittee which collected the data decided in May 1978 to keep it con. fidential and formally refused to grant us access to it. 